\title{
Changes in production systems and effects on parasitic infections
}

\author{
Allan Roepstorff", Stig Milan Thamsborg, Helena Mejer \\ From Parasite infections of domestic animals in the Nordic countries - emerging threats and challenges. \\ The 22nd Symposium of the Nordic Committee for Veterinary Scientific Cooperation (NKVet) \\ Helsinki, Finland. 7-9 September 2008
}

\section{Summary}

A plentity of parasites of great diversity is the rule for all animals in nature. A successful parasite has to be transmitted from one host to the next and this transmission is often the weakest point in the life cycle, as the parasites depend on the surrounding environment for days to months to become infective either as free-living stages or within intermediate hosts. For domestic animals, housing and other factors characterizing the production system thus have a great impact on transmission, the ectoparasites being an exception due to their transmission by physical contact between host animals. In the present paper, the effects of production systems on parasitic infections are discussed with focus on pigs. During the last century pigs have moved from traditional husbandry systems with poor hygiene and access to outdoor areas towards highly intensive, exclusively indoor industries, a process which has gradually reduced the number of endoparasite species. Furthermore, ectoparasitic arthropods are easily eradicated by drug treatment in modern pig enterprises. It is thus only a small number of protozoan parasites that are common across farms. At present, the trend of decreasing parasitism is for the first time reversed. Organic pigs or other free-range pigs make up the best and most extreme example, and these pigs may harbour many more parasites than conventional pigs. Only a small minority of domestic pigs, however, live in organic/freerange herds. It may therefore be more important in the future that conventional pig herds are also changing their housing system due to animal welfare issues; straw bedding is being reintroduced, the pregnant sows are

Danish Centre for Experimental Parasitology, Department of Disease Biology, Faculty of Life Sciences, University of Copenhagen, Dyrlægevej 100, DK-1870 Frederiksberg C, Denmark

Full list of author information is available at the end of the article untethered to become free-moving, and facilities may include water sprinkling devices which will increase the humidity and thereby the survival of transmission stages. The future challenge of domestic pigs may therefore, for the first time, be to control an increasing parasite load.

Published: 13 October 2010

doi:10.1186/1751-0147-52-S1-S26

Cite this article as: Roepstorff et al:: Changes in production systems and effects on parasitic infections. Acta Veterinaria Scandinavica 2010 52(Suppl 1):S26.

\section{Submit your next manuscript to BioMed Central and take full advantage of: \\ - Convenient online submission \\ - Thorough peer review \\ - No space constraints or color figure charges \\ - Immediate publication on acceptance \\ - Inclusion in PubMed, CAS, Scopus and Google Scholar \\ - Research which is freely available for redistribution \\ Submit your manuscript at www.biomedcentral.com/submit}

